\title{
REFUGEES AND INTERMEDIATE DISPLACED PERSONS IN ZEMUN MUNICIPALITY
}

\author{
Aleksandar Kovjanić ${ }^{* 1}$ \\ "University of Belgrade - Faculty of Geography, Belgrade
}

\begin{abstract}
The municipality of Zemun is Belgrade municipality with highest number of war-endangered persons. Refugee status or status of internally displaced persons still have over 8,000 inhabitants of this municipality. Intensive influx of forced migrants in last decade of XX and at the beginning of XXI century, has led to demographic and physiognomic changes that were analysed in this work. It has past more than 20 years since the settlement of first forced migrants, building now settlements and expending existing ones, and many problems of this endangered community are resolving slowly or not resolving at all. Among the major problems are unsolved status issues of refugees and intermediate displaced persons, incomplete integration, expansion of unplanned and infrastructural unregulated settlements.
\end{abstract}

Key words: refugees, intermediate displaced persons, migrations, integration, Zemun, urbanization, pseudo-urbanization.

\section{Introduction}

The disintegration of SFR Yugoslavia, in perennial years of conflict, resulted in the exodus of millions of people. At the beginning of disintegration of SFR Yugoslavia, the first forced migrants from Slovenia, Croatia, Bosnia and Herzegovina and Macedonia arriving in Serbia. With the outbreak of the

${ }^{1}$ Corresponding author: A. Kovjanić, University of Belgrade - Faculty of Geography, Studentski trg 3/III, 11,000 Belgrade, Serbia; e-mail: kodza90@hotmail.com 
war in Croatia in 1991 and in B\&H in 1992, the number of refugees increases. The largest number of refugees arrived in Serbia, at the same time in Zemun municipality, in August 1995, after the fall of the Republika Srpska Krajina and persecution of Krajina Serbs. The second wave of forced migration occurs after the conflict in Kosovo and Metohija and NATO aggression in 1999.

Forced migration and migrants represent comlpex and interdisciplinary phenomenon. Number of forced migrants in the world is constantly increasing, which is why the research of this specific population is of great importance. According to the last data from 2016 around the world were $65.6 \mathrm{mil}-$ lions of forced displaced people. From total population of forced migrants $2 / 3$ of them are IDPs and asil seekers (43.1 million) and refugees 1/3 (22.5 million) (UNHCR, 2017). Serbia, with an aproximate 250,000 refuges and displaced persons, in 2016 was at $41^{\text {st }}$ place in the world and sixth in Europe by the size of this population (UNHCR, 2017). From 1993 till 2005 Serbia continuosly was in group of 20 states with highest number of refugees in the world. ${ }^{2}$ Also, apart from the traditionally crisis world warfare, the refugee crisis that has been going on since the beginning of second decade of the XXI century is one of the greatest contemporary problems in Europe. From these reasons, domestic and foreign authors are showing more and more interest in this topic.

The study of refugees and IDPs, factors that influence their occurrence, multiple changes and influences which hapening in space are dealing by geographers, demographers, spatial planners, lawyers, political scientists, sociologists, historians, ethnologists and others. The authors mainly deal with the problems of integration of refugees and displaced people (Landau, Jacobsen, 2004, Vujadinović et al., 2011, Rakić, 2012, Стајић, Штрбац, 2013, Block, et al., 2013, Šabić et al., 2013, Penninx, Garcés-Mascareñas, 2016, Лукић, 2016, Moore, 2017, Parsloe, 2017) and the impact of this population on the socioeconomic transformation of new environment (Трипковић, 2005, Кокотовић, Филиповић, 2013, Devictor, 2017, Jacobsen, 2017, Parsloe, 2017). Jakobsen (2017) believes that in the case of forced migrants, research at the local level (cities, settlements, refugee neighborhoods) is necessary versus national or global, to understand the impact of this population on city governance, work of local services, social cohesion, housing construction, public infrastructure, transport, education, health, trade, services. The attention of scientific public is also focused on theoretical and methodological issues. Among them, the reliability of relevant data sources, the accuracy of statistical data and the results of the research being based on them and their conclusions are high-

${ }^{2}$ http:/ / www.unhcr.org/56655f4b19.html 
lighted (Vigneswaran, Quirk, 2013, Block, et al., 2013, O’Byrne, 2013, Лукић, 2015, Devictor, 2017), methodological problems of researching itself and improvement of research techniques (Vigneswaran, Quirk, 2013, Block, et al., 2013). Richmond (1993) and Black (2001) criticize the definition of forced migrants by UN Convention relating to the Status of Refugees from 1951. This Convention and its provisions are still considered to be relevant, although there is an evident incompatibility with modern migration flows (Лукић, 2015). Similar doubts about the definition of the category of forced migrants and various interpretations are also quotes by the other authors (Hathaway, et al., 2013, O’Byrne, 2013, Kuti, 2014).

\section{Methodology and data}

Although any forced migration from one state to another is an exile, the conception of refugees is not clear because of different determinations by various institutions, organizations, international and domestic law. Refugees are persons who are considered refugees under the UN Convention relating to the Status of Refugees, International Law and the Law on Refugees of the Republic of Serbia (UNHCR, KIRS, 1996, Korać Mandić et al., 2006, Лукић, 2015). Also, displaced persons from Kosovo and Metohija are being lead as internally displaced persons (IDP), because they did not leave Serbia, they are Serbian citizens and displaced inside its territory (UNHCR, KIRS, 2000). Despite their different official status, their problems do not distinct significantly from problems that refugees have.

Statistic data about refugees and internally displaced persons can be found in the publications of the Commissariat for Refugees and Migration (UNHCR, KIRS, 1996, UNHCR, KIRS, 2000, UNHCR, KIRS, 2002, UNHCR, KIRS, 2007, KIRS, 2009) $)^{3}$ and in the publications of the Republic Institute for Statistics which data are based on the results of the population census (Лађевић, Станковић, 2004, Лукић, 2015). In studying refugees and IDPs, there is a problem of inaccuracy, incompatibility and lack of data. Inaccuracies and incomparability result from the different methodology by which these persons are registered, due to different years of registration and the change in the municipal border in 2004. Certain parameters and structures of the population are not treated and presented in the same way in publications, which makes it impossible to manage a collective analysis for both

${ }^{3}$ Data by municipalities were not published after 2009, but can be found on the website of the Commissariat for Refugees and Migration. 
groups of displaced persons. In the Commissariat's publications, the presented data refers only to persons with recognized refugee status and IDPs status. These data will be used in the work. The population of persons with refugee status and status of IDPs has been known for the past 10 years based on people who are extending refugee and IDPs identity card.

\section{Population of refugees and internally displaced persons}

The first post-war census of refugees and other war-affected persons from 1996, the number of registered forced migrants in Serbia amounted to 618 181 . Out of that number, 537,937 persons $(87 \%)$ had refugee status and 80,244 persons $(13 \%)$ were defined as other war endangered persons who according to international and domestic legal norms do not have the right to a refugee status, mainly because of possession of Serbian citizenship (UNHCR, KIRS, 1996). The Government of FRY considered that the actual number of forced migrants exceeds the number of those who are registered by about 20\% (Ilić, 2001). With 140,662 refugees (26.2\%), the City of Belgrade represented their significant destination due to increased opportunities for employment, accommodation and education. Among the municipalities of Belgrade, with the largest number of refugees $\left(22,085^{4}\right)$, the municipality of Zemun was distinguished. Of the total refugee population on the territory of the municipality of Zemun moved in $4.1 \%$ of refugees or more exactly $15.7 \%$ of the refugees in the territory of the City of Belgrade. Most were refugees from Croatia (61.1\%), while the rest were mostly from $\mathrm{B} \& \mathrm{H}$. More refugees were registered only in the municipalities of Novi Sad $(40,602)$ and Loznica $(26,379)$ (UNHCR, KIRS, 1996).

New forced migrants settled throughout Central Serbia and Vojvodina after the outbreak of conflict in Kosovo and Metohija in 1998 and NATO aggression against Serbia in 1999. The first registration of IDPs was organized in 2000, when 187,129 were registered. The largest number of IDPs had a temporary residence in Belgrade (53,013 or $28.3 \%$ ) and of that number 5,931 in the municipality of Zemun. More number of IDPs lived in Kraljevo, Kragujevac, Niš, Kruševac, Smederevo and the Belgrade municipality of Voždovac. ${ }^{5}$

\footnotetext{
${ }^{4}$ Besides the refugees, 3,667 other war-affected persons were registered, so the total number of forced migrants in the Zemun municipality amounted to 25,752 (UNHCR, KIRS, 1996).

${ }^{5}$ http://www.kirs.gov.rs/docs/statistika/izbirl2016.pdf
} 
Refugees and Intermediate Displaced Persons in Zemun Municipality

Table 1 - Comparative overview of the number of refugees and IDPs in Zemun Municipality ${ }^{6}$ 1996-2016.

\begin{tabular}{|l|c|c|c|c|c|c|c|c|c|c|c|c|c|}
\hline Year & $\mathbf{1 9 9 6}$ & $\mathbf{2 0 0 0}$ & $\mathbf{2 0 0 1}$ & $\mathbf{2 0 0 4}$ & $\mathbf{2 0 0 8}$ & $\mathbf{2 0 0 9}$ & $\mathbf{2 0 1 0}$ & $\mathbf{2 0 1 1}$ & $\mathbf{2 0 1 2}$ & $\mathbf{2 0 1 3}$ & $\mathbf{2 0 1 4}$ & $\mathbf{2 0 1 5}$ & $\mathbf{2 0 1 6}$ \\
\hline Refugees & 22,085 & $/$ & 24,847 & 7,942 & 6,144 & 5,513 & $/$ & 4,461 & 4,030 & 3,576 & 2,639 & 2,035 & 1,908 \\
\hline IDP & $/$ & 5,931 & $/$ & $/$ & 6,877 & $/$ & 6,696 & 6,681 & 6,658 & $/$ & 6,212 & 6,249 & 6,244 \\
\hline Total & $/$ & $/$ & $/$ & $/$ & 13,021 & $/$ & $/$ & 11,142 & 10,688 & $/$ & 8,851 & 8,284 & 8,152 \\
\hline
\end{tabular}

Source: http://www.kirs.gov.rs/docs/statistika/izbirl2016.pdf

The following registration of refugees and IDPs shows significant changes in this population. It happens due the influx of new refugees and IDPs, repatriation (return), going to third countries, and the effects of birth and mortality. By the next census of refugees in 2001, their number in Serbia has gone down by 159,348 or $29.6 \%$, and in Belgrade by 27,082 or $19.3 \%$. In spite of that, the number of refugees in Zemun municipality increased by 2,762 or $12.5 \%$. For a short period of five years, refugee distribution has changed significantly. Belgrade and the municipality of Zemun (24,447 refugees, with a share of $21.9 \%$ within Belgrade) have still represented half the concentration of the refugee population. With the third census, organized at the end of 2004 and beginning of 2005, it has been carried out a new registration and revision of persons with refugee status. As a result of easier procedures for obtaining Serbian citizenship and ID card, the number of refugees has been rapidly reduced. At that time about 250,000 people gained Serbian citizenship, which is the largest process of integration of refugees in modern Europe (Влада Републике Србије, 2011). That way the number of refugees in the Zemun municipality decreased by 16,905 or $68 \%$ compared to 2001 . The number of refugees in the following period had a constant and relatively uniform tendency of decline. After the first census, IDPs continued to move into the Zemun municipality. At the first following registration in 2008, their largest number was registered $(6,877)$. In the following period, the number of IDPs decreased with a lower intensity, with a slight increase from 2014 to 2015 (Table 1).

${ }^{6}$ Data for refugees until 2008 include persons who lived in the settlements of the current municipality of Surčin. 


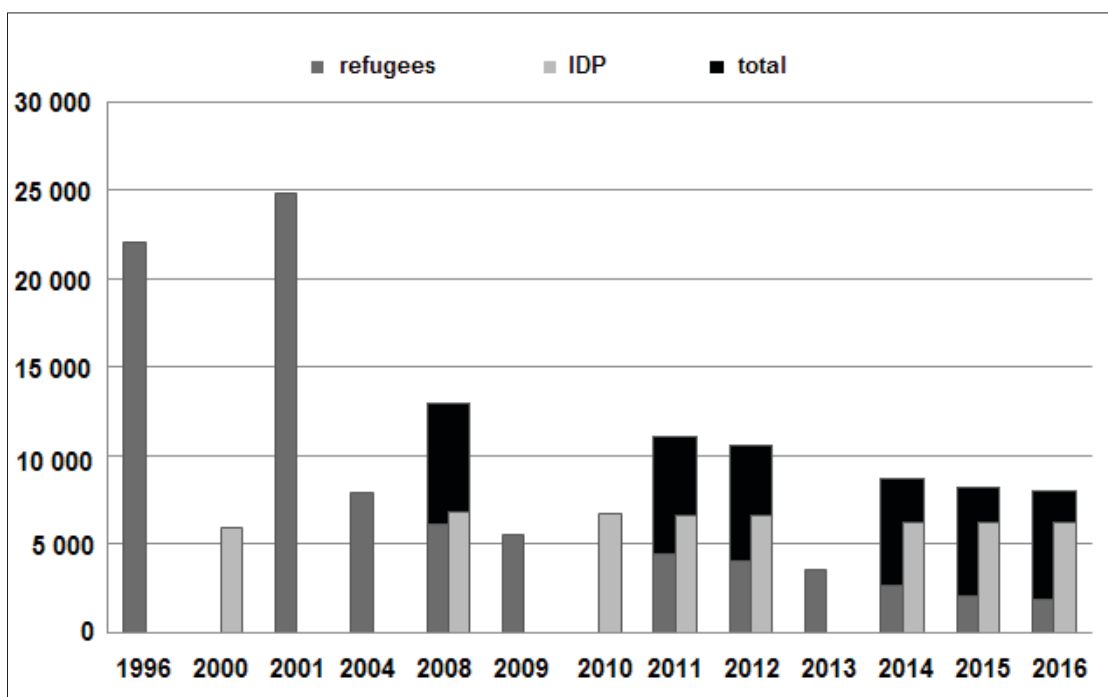

Figure 1 - Refugees and IDPs in Zemun municipality by age of registration Source: Commissariat for Refugees and Migration

Collective data on both groups of migrants can be monitored since 2008 when the total number of forced migrants amounted to 13,021. In the 2011 census, their share in the total population of the municipality was $6.6 \%^{7}$. According to the latest data from 2016, in the municipality of Zemun, 1,908 refugees and 6244 IDPs or in total of 8,152 forced migrants were registered. Compared to 2008 , the total number of forced migrants is 4,869 or $37.4 \%$ lower, mostly due to the legal integration of refugees. According to the number of members of these two endangered populations, in 2016 Zemun municipality was in the fifth place after Kraljevo, Kragujevac, Niš and Smederevo.

\section{Consequences, situation and problems}

The objective of each country and local administration is to reduce the number of refugees and IDPs as effectively as possible in a shorter period and solve the essential problems of this population. There are three possible ways - integration, repatriation (return) and migration to third countries

${ }^{7}$ According to the results of the 2011 census, according to a different methodology where refugee population is separated, their share in the Zemun municipality is 12.7\% (Лукић, 2015). 
(Влада Републике Србије, 2011). The implementation of these solutions is not possible without support of international factors, humanitarian organizations and mutual cooperation of countries that are affected by this problem. The goal of all declarations, resolutions, strategies and conferences was the same - solving the refugee and IDP problems and closing this issue. There were positive effects, but this vulnerable population and its problems are still present, throughout Serbia, as well as in the Zemun municipality.

According to the number of refugees and IDPs and their share in the total population the Municipality of Zemun was and remained among the leading municipalities in Serbia for two decades. Their spatial distribution within the municipality is not evenly balanced. The highest concentration of refugees and IDPs is in suburban and rural settlements ${ }^{8}$ : Batajnica, Zemun Polje, Altina, Plavi Horizonti, Ugrinovci, Busije and Grmovac. A smaller part of this population lives in the urban part of Zemun, built until the 1990s. In the peri-urban zone of Belgrade, more exactly Zemun, as its urban part, there are favorable conditions for business, employment, development of crafts, small economy, agriculture, construction of housing, production and storage space, because there are lower prices of land, houses, apartments and annuities in relation on the narrow core of Zemun (Матијевић et al., 2005). Beside that, in the Zemun municipality, before the outbreak of the conflict, lived people who were originatly from these areas, so a considerable number of expelled was or stayed with friends and relatives. The temporary accommodation solution was provided by collective centers. The last collective center in Zemun municipality ",7. juli“ was closed in 2012.

Since the 1990s, the process of population and urban expansion and transformation has been taking place in Zemun municipality. Since 1991 $(146,056)$, the population of Zemun municipality has grown by 22,114 inhabitants or 15\% by $2011(168,170)$. Most of the refugees and IDPs contributed to this. Besides the absolute increase in population, there has been a smaller change in the age structure. Refugees and IDPs are in average younger than the local population of the municipality ${ }^{10}$. There was a significant impact on the change in the ethnic structure. From the period of immigration of the ex-

${ }^{8}$ Except Zemun, a higher presence of refugees and IDPs is recorded among Belgrade municipalities, in suburban and rural settlements of Čukarica, Palilula, Voždovac, Zvezdara and Grocka.

${ }^{9}$ http:/ / www.kirs.gov.rs/articles/centri.php?lang=SER

10 The young population of internally displaced persons in the municipality accounted for $46.5 \%$ of the population (UNHCR, KIRS, 2000). 
iles, there was ethnic homogenization in favor of the Serbs. In 1991 the Serbs accounted for $80 \%$ and in $201189 \%$ of the population of Zemun municipality.

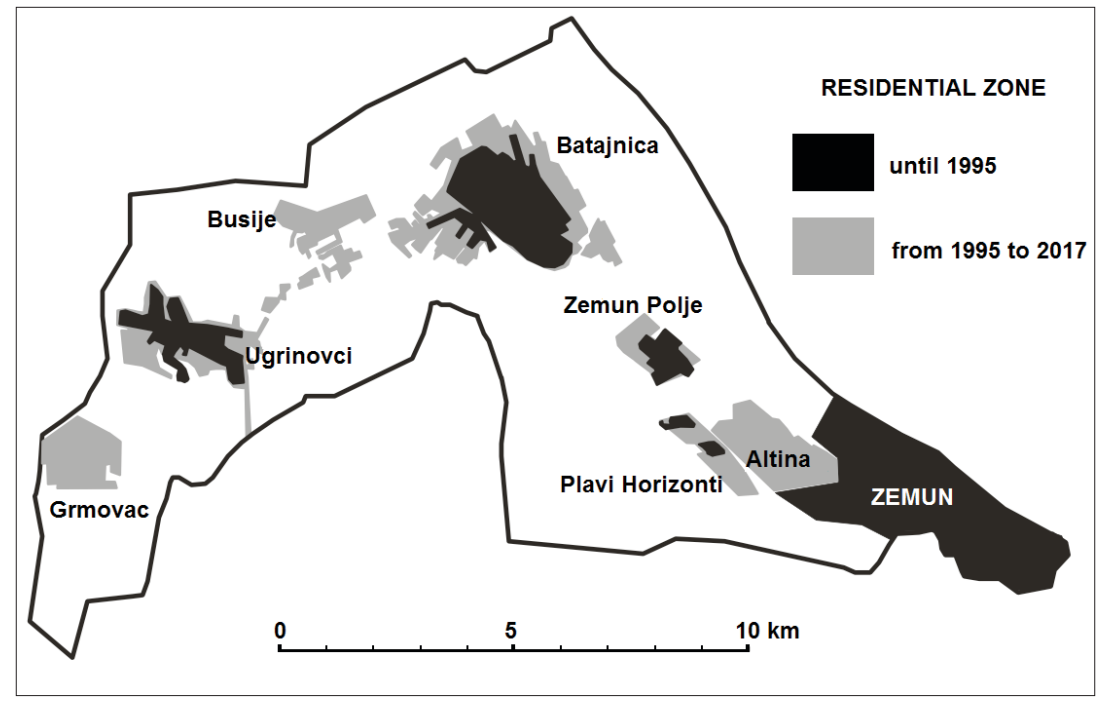

Figure 2 - Expansion of the residential zone in Zemun municipality in period 1995-2017.

The settlement of a large number of people in a relatively short period of time resulted in the expansion of the existing ones (Batajnica, Ugrinovci, Zemun Polje) and the building of new settlements (Altina, Plavi Horizonti, Busije, Grmovac). Stirred, spontaneous urbanization was followed by illegal construction. The unplanned expansion of the city territory, that is the housing zone in the peripheral parts, was carried out at the expense of agricultural land. So, for example, Busije, a settlement located between Ugrinovci and Batajnica, founded on the land of PIK Napredak, and Altina on the land of PIK Zemun. As a result of that, the settled population can not convert the land from agricultural to construction and legalize theirs facilities. The existing settlements were infrastructurally regulated, according to the size and functions of the time, whereas the area where new settlements were built was not intended for housing construction and had no any infrastructure. Infrastructure investment in the following period was not proportionate to the population dynamics and spatial-functional transformation of this part of municipality and existing settlements. Electricity was introduced step by step, water sup- 
ply system, bus lines. Access roads and streets were built. The side streets are mostly macadam and been asphalted only in recent years. There are insufficient number of schools, kindergartens, health centers and outpatient clinics, sports and recreational terrains. There is a plan of continuing construction of the sewerage system. Because of the slow functioning of local administration, the locals financed the construction of the infrastructure themselves. And after 20 years since the first houses were lifted, these settlements remained more or less infrastructurally unregulated. The best example is Grmovac, which inhabitants lived and still living in inadequate conditions. Grmovac is the smallest $^{11}$ and furthest settlement from the municipal center (the only settlement on the south side of the highway). Although it is located along the highway, the absence of a direct, closest exit to the highway makes it the most isolated settlement in the municipality. The settlement began to build in 1997 on the agricultural land of the PKB. The citizens of Grmovac did not have electricity for 10 years, and they waited until 2011 for the construction of the water supply system. Since the pipes did not go through the entire settlement, a part of the population still does not have water. Only two streets are asphalted, and the bus line was established in 2009. In Grmovac there is no school, kindergarten, post office, infirmary, playground for children, sewage.

\section{Conclusion}

The number of refugees and IDPs in the Zemun municipality has been significantly reduced in the past 20 years. The reduction of this vulnerable population came mainly due to legal integration, i.e. the acceptance of Serbian citizenship (for refugees) and ID card with the address in the Zemun municipality. More than 8,000 refugees and IDPs have maintained refugee/ IDPs legitimation and status. It is considered that the sense of security that this status gives them the main reason for its retention. In case of deletion from the register of refugees or displaced persons, they lost certain benefits and the right to apply for various assistance programs (Лукић, 2015).

The intensive migration movements caused certain demographic changes in the municipality. They most clearly reflected on changes in space, through the increasing of the residential zone. Building new ones and expanding existing settlements is supported in order to solve the residential needs of displaced persons. Except assistance to provide cheap plots and building materials, the Municipality and the City have not long shown inter-

${ }^{11}$ According to the local words Grmovac have about 1,000 inhabitants. 
est in solving key problems in these settlements. In the last 10 years, there have been noticed increased infrastructure works and investments of the Municipality of Zemun and the City of Belgrade. Many problems have not been resolved, institutions of general interest (health institutions, schools, kindergartens), street roads with a sidewalk, developed public transport lines, plumbing and sewerage network, green areas, sports and recreational facilities are missing. Organization of settlements and construction of infrastructure contents that exist in other parts of Zemun and Belgrade are hampered by the slow administrative procedure and the problem of legalization, not only of individual facilities, but of the entire settlements.

It is still necessary to provide continuous support and better conditions for all refugees and internally displaced populations in the process of their full integration, regardless of status. Although the largest number of refugees and displaced persons is officially integrated in time, integration itself is a complex process and does not involve the automatic and rapid solving of their existential problems and life needs.

\section{Acknowledgements}

The paper is the result of the research within the project no. 176008 funded by the Ministry of Education and Science of the Republic of Serbia.

\section{References}

Black, R. (2001). Fifty Years of Refugee Studies: From Theory to Policy. International Migration Review, 35(1), 57-78.

Block, K., Warr, D., Gibbs, L. and Riggs, E. (2013). Addressing Ethical and Methodological Challenges in Research with Refugee-background Young People: Reflections from the Field. Journal of Refugee Studies, 26(1), 69-87.

Devictor, X. (2017). Towards a development approach to displacement. Forced Migration Review, 56, 73-75.

Hathaway, J. C., North, A. M. and Pobjoy, J. (2013). Supervising the Refugee Convention: Introduction. Journal of Refugee Studies, 26(3), 323-6.

Ilić, V. (2001). Između integracije i održivog povratka: izbeglice u Srbiji. Beograd: Helsinški odbor za ljudska prava u Srbiji.

Jacobsen, K. (2017). Refugees in towns: experiences of integration. Forced Migration Review, 56, 78-79. 
KIRS (2009). Stanje i potrebe izbegličke populacije u Republici Srbiji. Beograd: Komesarijat za izbeglice Republike Srbije.

Korać Mandić, D., Opačić, N., Škorc, B., Ćirić, D., Volarević, S. i Muždeka, N. (2006). Integracija kao dugoročno rešenje za izbeglice i raseljena lica u Srbiji: analitički izveštaj. Novi Sad: Srpski savet za izbeglice.

Kuti, S. (2014). Izbjegličke studije i migrantski transnacionalizam: od ignoriranja do novih mogućnosti. Polemos, 17(33-34), 29-47.

Landau, L. B. and Jacobsen, K. (2004). Refugees in the new Johannesburg. Forced Migration Review, 19, 44-46.

Moore, B. (2017). Refugee settlements and sustainable planning. Forced Migration Review, 55, 5-7.

O'Byrne, K. (2013). Is there a Need for Better Supervision of the Refugee Convention? Journal of Refugee Studies, 26(3), 330-359.

Parsloe, T. (2017). Appropriating buildings to house refugees: Berlin Tempelhof. Forced Migration Review, 55, 35-36.

Penninx R. and Garcés-Mascareñas, B. (2016). The Concept of Integration as an Analytical Tool and as a Policy Concept. In: Garcés-Mascareñas B., Penninx R. (Eds.) Integration Processes and Policies in Europe. Cham: Springer, 11-29.

Rakić, D. (Ur.) (2012). Izazovi prisilnih migracija u Srbiji: položaj izbelica, interno raseljenih lica, povratnika i tražilaca azila. Beograd: Grupa 484.

Richmond, A. H. (1993). Reactive Migration: Sociological Perspectives On Refugee Movements. Journal of Refugee Studies, 6(1), 7-24.

UNHCR, KIRS (1996). Popis izbeglica i drugih ratom ugroženih lica u Saveznoj Republici Jugoslaviji. Beograd: Komesarijat za izbeglice Republike Srbije i Komesarijat za raseljena lica Republike Crne Gore.

UNHCR, KIRS (2000). Registracija lica raseljenih s Kosova i Metohije. Beograd: Komesarijat za izbeglice Republike Srbije i Biro za humanitarnu pomoć Evropske unije.

UNHCR, KIRS (2002). Registracija izbeglica u Srbiji mart - april 2001. Beograd: Komesarijat za izbeglice Republike Srbije i Biro za humanitarnu pomoć Evropske unije.

UNHCR, KIRS (2007). Izveštaj sa registracije izbeglica u Republici Srbiji 2005. godine. Beograd: Komesarijat za izbeglice Republike Srbije.

UNHCR (2017). Global Trends: Forced Displacement in 2016. Geneva: United Nations High Commissioner for Refugees. 
Vigneswaran, D. and Quirk, J. (2013). Quantitative Methodological Dilemmas in Urban Refugee Research: A Case Study of Johannesburg. Journal of Refugee Studies, 26(1), 110-116.

Vujadinović, S., Šabić, D., Stojković, S. and Milinčić, M. (2011). Years of Refugee Life in Serbia - Challenges for a New Beginning: Stay or Return Home? Trames, 15(3), 235-258.

Šabić, D., Knežević, A., Vujadinović, S., Golić, R., Milinčić, M. and Joksimović, M. (2013). Belgrade Slums - Life or Survival on the Margins of Serbian Society? Trames, 17(1), 55-86.

Влада Републике Србије (2011). Национална стратегија за решавање питања избеглица и интерно расељених лица за период од 2011. до 2014. године. Београд: Влада Републике Србије.

Кокотовић, В. и Филиповић, М. (2013). Избеглище у Србији - након двадесет година. Зборник радова Географског института Јован Цвијић, 63(1), 27-39.

Лукић, В. (2015). Две деценије избеглиштва у Србији. Попис становништва, домаћинстава и станова 2011. у Републици Србији. Београд: Републички завод за статистику.

Лукић, В. (2016). Интеграција присилних миграната из бивших република СФРЈ на тржиште рада у Србији. Демографија, XIII, 83-94.

Матијевић, Д., Тошић, Б. и Лукић, В. (2005). Утицај миграција на популационе и функционалне промене сремских општина. Гласник С пског географског друштва, 85(1), 111-120.

Стајић, Љ. и Штрбац, К. (2013). Улога међународних хуманитарних организација у збивањима на Западном Балкану (Случај Србија). Зборник радова Правног факултета у Новом Саду, 2, 147-162.

Трипковић, Г. (2005). Избеглице - културни и социјални изазов. Социолошки преглед, XXXIX (1), 33-45.

http://www.kirs.gov.rs

http:/ / www.unhcr.org

*** Становништво према националном саставу (1991). Попис становништва 1991. Београд: Савезни завод за статистику.

*** Национална припадност (2012). Попис становништва, домаћинстава и станова 2011. у Републици Србији. Београд: Републички завод за статистику. 